\title{
How to Increase Islamic Banking Profit Growth in Indonesia?
}

\author{
Delli Maria $^{1}$, Faurani Singagerda ${ }^{2}$, Maharani $^{3}$ \\ \{delli.maria@darmajaya.ac.id ${ }^{1}$, fsingagerda@gmail.com², maharani@gmail.com ${ }^{3}$ \} \\ ${ }^{1,3}$ Informatics and Business Institute Darmajaya, Dept. of Accounting, Indonesia \\ ${ }^{2}$ Informatics and Business Institute Darmajaya, Dept. of Management, Indonesia
}

\begin{abstract}
This research aims to prove empirically whether applying maqashid sharia and the maximal role of the sariah supervisory board on sharia operations can lead to positive profit growth in Islamic banks in Indonesia. The performance of maqashid sharia is measured using the Maqashid Shariah Index (MSI) while the sharia supervisory board is measured using the number of sharia supervisory boards. This study uses a purposive sampling method, in order to obtain eleven Islamic banks registered. Hypothesis testing using multiple linear regression. The results of this research found that applying of maqashid sharia and the maximal role of the sharia supervisory board could lead to positive profit growth in Islamic banking in Indonesia.
\end{abstract}

Keyword: Maqoshid Sharia, Profit Growt Islamic Bank, Sharia Supervisory Board

\section{Introduction}

The ability bank to earn profits is one indicator that the bank has run its operations efficiently and has good performance and business prospects [1][2]. Profit growth indicates a good financial condition of the company, good company conditions will increase the value of the company. Companies with growing profits will have a large amount of assets so that they can provide greater opportunities in generating profits. Increased profits can cause increase dividends share. The increase dividends share will affect investors' decisions to invest their capital in the company.

In fact, there was a decrease in profitability in Islamic banking in Indonesia. Graph 1.1 below shows the decline in profit and loss experienced by Islamic banks in Indonesia in the 2014-2017 period.

Graph. 1.1 Profit and Loss Islamic Bank

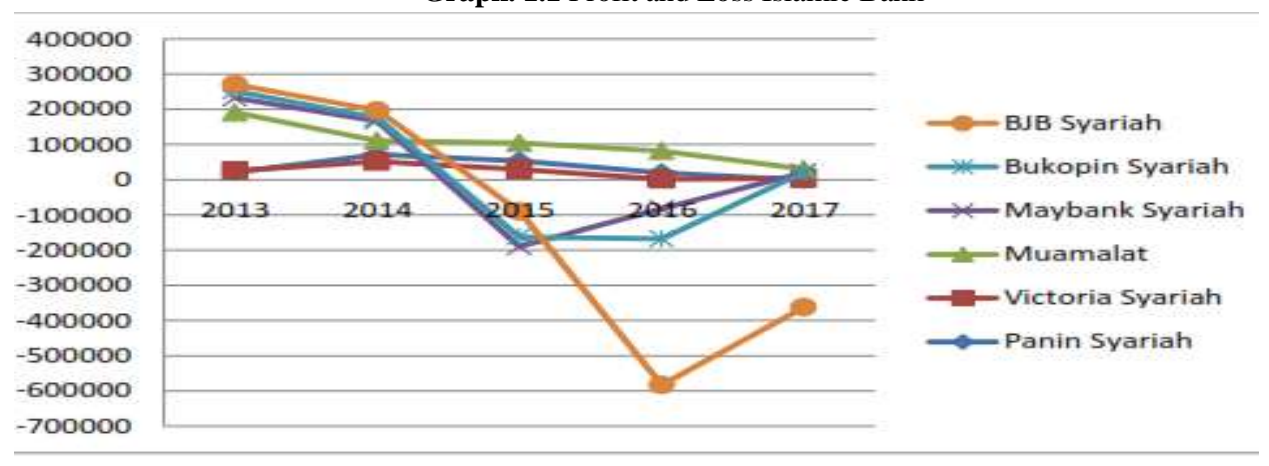


Islamic banking profit growth has decreased evenly, both Bank Muammalat Indonesia, which is the first bank according to Sharia, to the new Islamic bank. What coused it? How to increase islamic banking profit growth, in a predominantly Muslim society?

The application of Maqoshid sharia to Islamic banking can increase public trust [3][4][5][6]. Public trust in sharia compliance in islamic banking operations can increase the public's desire to invest in islamic banking. Increased investment from the public can accelerate profit growth [7][8].

The fundamental difference between islamic banking and conventional banking is the purpose of banking itself. The establishment of islamic banks aims not only to achieve maximum profits but must also strive to realize maqashid sharia [5][8][3]. The concept of sharia maqashid aims to realize benefit in the world and the hereafter. This concept contains justice, mercy, benefit and also wisdom for all humanity. So the measurement of islamic banking performance must focus on the achievement of maqashid sharia. Mohammed M.O Razak, found measurements of Maqosid Sharia implementation using the Maqashid Sharia Index (MSI). MSI measurement consists of three main objectives namely educating individuals (Tahdzib al-Fardi), upholding justice (Iqamah al-Adl), and achieving welfare or welfare (Jalb al-Maslahah). The concept is then operationalized through the now method so that it can be measured parameters.

The implementation of maqoshid sharia requires supervision [9][7]. In line with the wishes of the public who want Islamic banking to show responsibility related to their operational activities which are expected to comply with Islamic provisions and principles, a corporate governance mechanism is established namely the Sharia Supervisory Board (SSB). The sharia supervisory board is tasked with supervising banks to always comply with Islamic sharia, and to ensure that none of the bank's operational activities violate Islamic sharia [10] [11]. With the sharia supervisory board, it is hoped that the management will not violate contracts with customers, so that banks can operate optimally and can improve the performance of the bank itself [11]

The results of this study will answer the question, whether applying maqoshid sharia and the maximal role of the the sharia supervisory board in islamic banking can increase profit growth in islamic banking in Indonesia.

\section{Research Methods}

This study uses a purposive sampling method, namely Sharia Commercial Banks registered with the Financial Services Authority, OJK, and consistently publishes Good Corporate Governance (GCG) reports in the 2014-2017 period.

\subsection{Islamic Bank Profit Growth}

Earnings growth is the percentage increase in profits obtained by the company in a certain period. Optimal profit growth reflects the system contained therein has been running effectively and efficiently. Earnings information can be used as a reference for investors in making investment decisions. Earnings growth can be calculated:

$$
\text { Profit Growt }=\frac{\text { Net Profit This Years }- \text { Net Profit Last Years }}{\text { Net Profit Last Years }}
$$

\subsection{Maqashid Sharia Performance Measurement Model}


Performance measurement of islamic banks based on maqashid sharia is a process of determining whether Islamic banks can achieve goals derived from the concept of Islamic Maqashid. In measuring maqashid sharia, several indicators of performance attainment are used which include educating individuals, upholding justice and improving welfare. Three stages in measuring the performance of maqashid sharia, namely:

1. Assess the performance ratio of each maqashid sharia, including:

a. Educational assistance / total burden (R1.1)

b. Research load / total load (R2.1)

c. Training load / total load (R3.1)

d. Promotional expenses / total expenses (R4.1)

e. Net profit / total income (R5.2)

f. Mudharabah \& musyarakah financing / total financing (R6.2)

g. Interest-free income / total income (R7.2)

h. Net profit / total assets (R8.3)

i. Zakat / net assets (R9.3)

j. $\quad$ Real sector investment / total investment (R10.3)

2. Determine the Performance Ratio

The next step is to perform multiplication operations between dimensions and performance ratios with each weight. Mathematically can be explained in the following models:

a. First Maqashid (Individuals Education)

$\mathrm{PI}(\mathrm{O} 1)=\mathrm{W} 1(\mathrm{E} 1 \times \mathrm{R} 1+\mathrm{E} 2 \times \mathrm{R} 2+\mathrm{E} 3 \times \mathrm{R} 3+\mathrm{E} 4 \times \mathrm{R} 4)$.

$\mathrm{PI}(\mathrm{O} 1)=$ The performance indicator for the first maqashid-individuals education

$\mathrm{W} 1=$ The weight of the first maqashid goal

E1,2,3,4 = First, second, third, and fourth element weights

$\mathrm{R} 1,2,3,4=$ The ratio of the first, second, third, fourth element

b. Second Maqashid (Enforce Justice)

$\mathrm{PI}(\mathrm{O} 2)=\mathrm{W} 2(\mathrm{E} 5 \times \mathrm{R} 5+\mathrm{E} 6 \times \mathrm{R} 6+\mathrm{E} 7 \times \mathrm{R} 7)$

$\mathrm{PI}(\mathrm{O} 2)=$ The performance indicator for the second maqashid- Enforce Justice

W2 $=$ The weight of the second maqashid goal

E5,6,7 = Weights of the fifth, sixth, seventh elements

R5,6,7 = The ratio of the fifth, sixth, seventh elements

c. Third Maqashid (Maintaning Benefit)

$\mathrm{PI}(\mathrm{O} 3)=\mathrm{W} 3(\mathrm{E} 8 \times \mathrm{R} 8+\mathrm{E} 9 \times \mathrm{R} 9+\mathrm{E} 10 \times \mathrm{R} 10)$

Benefit

PI $(\mathrm{O} 3)=$ The performance indicator for the third maqashid-Maintaning

W3 = The weight of the third maqashid goal

$\mathrm{E} 8,9,10=$ Weights of the eighth, ninth, and tenth

$\mathrm{R} 8,9,10=$ Ratio of theeighth, ninth, and tenth element

3. Calculating Maqashid Index

The next step is to calculate the maqashid index with the formula

Maqashid Indeks = PI (O1) + PI (O2) + PI (O3)

Maqashid Indeks $=$ Shariah Maqashid index value

$\mathrm{PI}(\mathrm{O} 1)=$ Total performance indicators for the first goal

$\mathrm{PI}(\mathrm{O} 2)=$ Total performance indicators for the second goal

PI $(\mathrm{O} 3)=$ Total performance indicators for the third goal 
The weight of the objectives and elements of sharia maqashid can be seen in the following table 1.1:

Table 1.1 Weight Of Each Objective And Element

\begin{tabular}{|c|c|c|c|c|}
\hline $\begin{array}{c}\text { Concept } \\
\text { (Purpose) }\end{array}$ & $\begin{array}{c}\text { Weight } \\
(\%)\end{array}$ & Dimention & Element & $\begin{array}{c}\text { Weight } \\
(\%)\end{array}$ \\
\hline \multirow{5}{*}{$\begin{array}{l}\text { 1. Individual } \\
\text { education }\end{array}$} & \multirow{5}{*}{30} & \multirow[t]{2}{*}{ D1.Advancing knowledge } & E1. Educational assistance & 24 \\
\hline & & & E2. Research & 27 \\
\hline & & D2. Apply and improve new skills & E3. Training & 26 \\
\hline & & D3. Create awareness of Islamic banks & E4. Publication & 23 \\
\hline & & \multicolumn{2}{|c|}{ Total } & 100 \\
\hline \multirow{4}{*}{$\begin{array}{l}\text { 2. Enforce } \\
\text { Justice }\end{array}$} & \multirow{4}{*}{41} & D4. Fair return & E5. Fair Return & 30 \\
\hline & & D5. Affordable products and services & E6. Distribution Function & 32 \\
\hline & & D6. Eliminating injustice & E7. Interest-free products & 38 \\
\hline & & \multicolumn{2}{|c|}{ Total } & 100 \\
\hline \multirow{5}{*}{$\begin{array}{l}\text { 3. Maintaining } \\
\text { Welfare }\end{array}$} & \multirow{5}{*}{29} & D7. Bank profitability & E8. Profit Ratio & 33 \\
\hline & & D8. Distribution income \& welfare & E9. Individual Income & 30 \\
\hline & & \multirow[t]{2}{*}{ D9. Investasi disektor riil } & E10. real sector investment ratio & \\
\hline & & & & 37 \\
\hline & & \multicolumn{2}{|c|}{ Total } & 100 \\
\hline
\end{tabular}

Source : [9]

\subsection{Sharia Supervisory Board}

Sharia supervisory board is an independent board, formed by the National Sharia Board and placed in banks whose business activities are based on sharia principles. In carrying out its functions, the sharia supervisory board must follow the fatwa of the National Sharia Council. In this research sharia supervisory board $=$ the mount of members of the sharia supervisory board

\section{Results and Discussion}

This study aims to obtain evidence whether the application of sharia maqashid and the Sharia Supervisory Board can increase sharia bank profit growth. Using data from eleven Islamic Banks in the year of observation. The classical test results show that, data is normally distributed, there is no heterokedacity, no autocorrelation and no multicellaritas.

\subsection{Hypothesis Testing}

The hypothesis of this study was tested with multiple linear regression. The test results can be seen in the table 4.1 below: 
Table 4.1 ANOVA ${ }^{\mathrm{a}}$

\begin{tabular}{|c|c|c|c|c|c|c|}
\hline \multicolumn{2}{|c|}{ Model } & Sum of Squares & Df & Mean Square & F & Sig. \\
\hline \multirow{3}{*}{1} & Regression & 78.712 & 2 & 15.742 & 3.209 & $.016^{\mathrm{b}}$ \\
\hline & Residual & 186.431 & 38 & 4.906 & & \\
\hline & Total & 265.143 & 43 & & & \\
\hline
\end{tabular}

a. Dependent Variable: Pertumbuhan Laba

b. Predictors: (Constant) Maqashid Sharia, Sharia Suvervisory Board

Based on table 4.1 ANOVA obtained a significant value of $0.016<0.05$ with a value of Fcount 3.209> F table 2.61. This indicates that this research model is appropriate.

Table 4.2 t-Test Coefficients ${ }^{\mathrm{a}}$

\begin{tabular}{|l|c|c|c|c|c|}
\hline \multirow{2}{*}{ Model } & \multicolumn{2}{|c|}{ Unstandardized } & Standardized & \multirow{2}{*}{ T } & \multirow{2}{*}{ Sig. } \\
\cline { 2 - 4 } & \multicolumn{2}{|c|}{ Coefficients } & Coefficients & & \\
\cline { 2 - 4 } (Constant) & -6.320 & 3.093 & Beta & & \\
\hline Maqashid Sharia & 23.916 & 8.626 & .408 & 2.773 & .009 \\
\hline $\begin{array}{l}\text { Sharia Supervisory } \\
\text { Board }\end{array}$ & 2.339 & .906 & .458 & 2.581 & .014 \\
\hline
\end{tabular}

a. Dependent Variable: Pertumbuhan Laba

The t-test results in table 4.2 show that maqoshid sharia and sharia supervisory board have a significant positive effect on the profit growth of islamic banks in Indonesia. These results indicate that if the application of maqashid sharia can increase profit growth. Likewise with the sharia supervisory board, if the sharia supervisory board works optimally in accordance with its function, it will increase profit growth in islamic.

\subsection{Discussion}

\subsubsection{Maqashid Sharia and Profit Growth in Islamic Bank}

Performance measurement of Islamic banks based on Maqashid Sharia is a process to determine whether Islamic banks can achieve goals derived from the Maqashid sharia concept ${ }^{[3][12][13]}$. Hypothesis testing results show that applying Maqasid shariah can lead to positive profit growth. If Islamic banking and financial products apply maqoshid sharia, companies will develop well and can respond to the changing business progress with ever-changing. With the rapid development and response of the product, it can increase profits and make a significant profit growth from the profit of the previous year If viewed from the sharia side, maqoshid sharia is a provision made by God for the order of the universe. QS. Annisa:13 “ These are the limits (imposed by) Allah. Whoso obeyeth Allah and His meseenger, He will 
take him enter Gardens underneath which river flow, where such will dwell for ever. That will be the great success".

\subsubsection{Sharia Supervisory Board and Profit Growth}

The results of testing this research hypothesis indicate that the presence of the Sharia Supervisory Board can cause positive profit growth. Sharia supervisory board is an organ that must be formed in Islamic banking to distinguish between GCG in conventional banks and Islamic banks. According to PBI number 11/33 / PBI / 2009 the Sharia Supervisory Board is a board that has the duty to provide advice and advice to directors as well as supervise the bank's operational activities to be in accordance with sharia principles. The sharia supervisory board has a role as a monitoring of islamic banks related to compliance with Islamic sharia so that it is expected to be able to suppress the existence of agency problems.

Sharia supervisory board influences banking profits ${ }^{[10][14]}$. The role of the sharia supervisory board which is very dominant for banking company operations is to maintain the trust of the public that the operational activities of sharia banks are carried out in accordance with sharia principles, so that the level of public trust in islamic banks is high and will increase the number of customers. With the increase in bank customers automatically the amount of income and profits also increases. Sharia supervisory board has an important role in the stability and performance of Islamic banks [9][11]. The number of DPS is greater with members who have various experiences and skills so that it leads to a better interpretation of the bank's products and operations and has an impact on better Islamic bank performance so that it can affect banking profit growth.

\section{Conclusions}

This research aims to prove empirically whether applying maqashid sharia and the maximal role of the sharia supervisory board on sharia operations can lead to positive profit growth in islamic banks in Indonesia. The performance of maqashid sharia is measured using the Maqashid Shariah Index (MSI) while the sharia supervisory board is measured using the number of sharia supervisory boards. This study uses a purposive sampling method, in order to obtain eleven islamic banks registered at the OJK as samples with a research period of 4 years, namely 2014-2017. Hypothesis testing using multiple linear regression with a confidence level of $95 \%$. The results of this research found that applying maqashid shariah and the maximal role of the sharia supervisory board could lead to positive profit growth in islamic banking in Indonesia.

\section{References}

[1] B. Pramuka, "Faktor-Faktor Yang Berpengaruh Terhadap Tingkat," J. Akuntansi, Manaj. Bisnis dan Sekt. Publik, vol. Vol.7 N0.1, no. Profitabilitas BUS, pp. 63-79, 2010.

[2] L. A. Prasetyowati and L. H. Handoko, "Pengukuran Kinerja Bank Umum Syariah Dengan Maqasid Index Dan Sharia Conformity And Profitability (SCNP)," J. Akunt. Dan Keuang. Islam, vol. 4, no. 2, pp. 107-130, 2019.

[3] D. Maria and F. Agustina, "Improvement of Maqoshid Shariah Performance," Saburai Int. J. Soc. Sci. Dev., vol. 2, no. 1, p. 78, 2018.

[4] K. Hadi, "Implementasi Maqoshid Syariah Sebagai Indikator Perusahaan Islami," J. 
AL-AZHAR Indones. SERI PRANATA Sos., 2012.

[5] T. M. Antonio Syafii, Sanrego D Yulizar, "an Analysis of Structure, Behavior and Banking Performance of Islamic Banking in Indonesia," J. Islam. Financ., vol. 1, no. 1, pp. 12-19, 2012.

[6] D. Maria and R. Mailiana, "Improving financial performance to social disclosure of Sharia bank performance based on Islamic Social Reporting Index," 3rd Int. Conf. Inf. Technol. Bus., pp. 77-84, 2017.

[7] V. R. Septiputri, "Dampak Corporate Governance Terhadap Profitabilitas Perbankan Syariah Indonesia Tahun 2007-2011," Akunt. Diponegoro, vol. 2, pp. 1-9, 2013.

[8] H. Hamza, "Sharia governance in Islamic banks: effectiveness and supervision model," Int. J. Islam. Middle East. Financ. Manag., vol. 6, no. 3, pp. 226-237, 2013.

[9] Waemustofa, Waeibrorheem, and A. Azrul, "Mode of Islamic Bank Financing: Does Effectiveness of Shariah Supervisory," Munich Pers. RePEc Arch., no. 72766, 2016.

[10] M. Amanullah, "Criteria of Shari'ah supervisory committee: A comparative study between guidelines of Bangladesh Bank and Bank Negara Malaysia," Intellect. Discourse, vol. 23, pp. 453-473, 2015.

[11] A. A. Khalid, H. Haron, A. M. Sarea, and T. A. Masron, "The role of shariah supervisory board on internal Shariah audit effectiveness: Evidence from Bahrain," Acad. Account. Financ. Stud. J., vol. 22, no. 5, p. 2635, 2018.

[12] E. Mutia and N. Musfirah, "Pendekatan Maqashid Shariah Index Sebagai Pengukuran Kinerja Perbankan Syariah Di Asia Tenggara," J. Akunt. dan Keuang. Indones., vol. 14, no. 2, pp. 181-201, 2017.

[13] W. Arafah and L. Nugroho, "Maqhashid Sharia in Clean Water Financing Business Model at Islamic Bank," Int. J. Bus. Manag. Invent., vol. 5, no. 2, pp. 22-32, 2016.

[14] N. M. Nomran, R. Haron, and R. Hassan, "Shari' ah supervisory board characteristics effects on Islamic banks' performance International Journal of Bank Marketing Article information :," no. March, 2016. 